\title{
Fall Risk in Patients with Ankylosing Spondylitis
}

\author{
Ankilozan Spondilitli Hastalarda Düşme Riski \\ Hakan ALKAN, ${ }^{1}$ Necmettin YILDIZ,,${ }^{1}$ Ayşe SARSAN, ${ }^{1}$ Nilgün ŞİMŞİR ATALAY, ${ }^{1}$ \\ Özgür SEVINCÇ, ${ }^{2}$ Oya TOPUZ, ${ }^{1}$ Füsun ARDIÇ ${ }^{1}$ \\ ${ }^{1}$ Department of Physical Medicine and Rehabilitation, Medical Faculty of Pamukkale University, Denizli, Turkey \\ ${ }^{2}$ Department of Public Health, Medical Faculty of Pamukkale University, Denizli, Turkey
}

\begin{abstract}
Objectives: The aim of this study was to investigate whether patients with ankylosing spondylitis (AS) have a higher fall risk than healthy subjects and to determine whether fall risk is associated with the clinical features of AS.
\end{abstract}

Patients and methods: Forty AS patients (28 males, 12 females; mean age $37.20 \pm 9.92$ years; range 20 to 60 years) who met the modified New York criteria and 40 age and gender-matched healthy controls were included. All participants were assessed by a static posturography device which provided numerical values in the percentage for fall risk. Patient interviews were used to assess the history of falls for the previous 12 months. The following tools were used for all AS patients: The Bath Ankylosing Spondylitis Disease Activity Index (BASDAl) for disease activity, the Bath Ankylosing Spondylitis Functional Index (BASFI) for function, the Bath Ankylosing Spondylitis Metrology Index (BASMI) for spinal mobility, and the Ankylosing Spondylitis Quality of Life (ASQoL) questionnaire for quality of life.

Results: There were no differences in the sociodemographic characteristics among the AS patients and the healthy controls ( $p>0.05)$. The mean fall risk was significantly higher for the AS patients compared to the controls $(p<0.05)$. The ratio of AS patients who had a positive history of falls was significantly higher than controls $(p<0.05)$. Fall risk was positively and significantly associated with the BASDAI $(r=0.713, p<0.001)$, BASFI $(r=0.751, p<0.001)$, BASMI $(r=0.527, p<0.001)$, and ASQoL $(r=0.627, p<0.001)$. The fall risk was not associated with the age, sex, body mass index and disease duration ( $p>0.05)$.

Conclusion: Fall risk increased in patients with AS which was associated with poor spinal mobility, functional status, quality of life and higher disease activity. Increased risk of falling should be taken into consideration in the rehabilitation of the patients with AS.

Key words: Ankylosing spondylitis; fall risk; posturography.
Amaç: Bu çalışmada, ankilozan spondilitli (AS) hastaların sağlıklı bireylerden daha fazla düşme riskine sahip olup olmadığı ve düşme riski ile AS'nin klinik özellikleri arasında herhangi bir ilişki olup olmadığı araştırıldı.

Hastalar ve yöntemler: Modifiye New York kriterlerine uyan AS'li 40 hasta (28 erkek, 12 kadın; ort yaş 37.20 9.92 yıl; dağılım 20-60 yıl) ile yaşları ve cinsiyetleri eşleştirilmiş 40 sağlıklı kontrol çalışmaya dahil edildi. Tüm katılımcılar, düşme riski yüzdesi olarak bize sayısal değerler sunan statik posturografi cihazı ile değerlendirildi. Hasta görüşmelerinden son 12 ay içindeki düşme öyküsü de belirlendi. Tüm AS hastalarına şu araçlar uygulandı: hastalık aktivitesi için Bath Ankilozan Spondilit Hastalık Aktivite Indeksi (BASDAI), fonksiyon için Bath Ankilozan Spondilit Hastalık Fonksiyonel İndeksi (BASFI), spinal mobilite için Bath Ankilozan Spondilit Metroloji Indeksi (BASMI) ve yaşam kalitesi için Ankilozan Spondilit Yaşam Kalitesi (ASQoL) anketi.

Bulgular: Ankilozan spondilitli hastalar ile sağlıklı kontroller arasında sosyodemografik özellikler bakımından fark yoktu ( $p>0.05)$. Ortalama düşme riski, AS'li hastalarda kontrollere kıyasla, anlamlı olarak yüksekti $(p<0.05)$. Ankilozan spondilitli hastalarda pozitif düşme öyküsüne sahip olanların oranı kontrollerden yüksekti $(p<0.05)$. Düşme riski ile BASDAI $(r=0.713, p<0.001)$, BASFI $(r=0.751$, $p<0.001)$, BASMI $(r=0.527, p<0.001)$ ve ASQoL $(r=0.627$, $\mathrm{p}<0.001)$ arasında pozitif ve anlamlı ilişki vardı. Düşme riski yaş, cinsiyet, vücut kütle indeksi ve hastalık süresiyle ilişkili bulunmadı ( $p>0.05)$.

Sonuç: Ankilozan spondilitli hastalarda kötü spinal mobilite, fonksiyonel durum, yaşam kalitesi ve yüksek hastalık aktivitesi ile ilişkili olan düşme riski artmıştır. Yüksek olan düşme riski AS'li hastaların rehabilitasyonunda dikkate alınmalıdır.

Anahtar sözcükler: Ankilozan spondilit; düşme riski; posturografi.

Received: August 08, 2012 Accepted: November 26, 2012

Correspondence: Hakan Alkan, M.D. Pamukkale Üniversitesi Tıp Fakültesi, Fiziksel Tıp ve Rehabilitasyon Anabilim Dalı, 20070 Denizli, Turkey.

Tel: +90 258 - 4440728 e-mail: alkangsc@yahoo.com

C2013 Turkish League Against Rheumatism. All rights reserved. 
Ankylosing spondylitis (AS) is a chronic, inflammatory rheumatic disease that primarily affects the axial skeleton, peripheral joints, and entheses. ${ }^{[1]}$ The clinical signs of the disease can range from mild stiffness to a totally fused spine and may include any combination of severe bilateral hip involvement, peripheral arthritis, or extraarticular manifestations. ${ }^{[2]}$

Ankylosing spondylitis is a disease with a varied natural history which sometimes has an insidious onset and slow progression. Predicting the course of the disease is difficult as periods of remission and relapse can occur at any stage. Additionally, even with treatment, permanent posture and movement problems, such as loss of spinal mobility, restriction of motions at peripheral joints, and decreased expansion of the chest ${ }^{[3]}$ can develop in patient with AS. Ventral flexion of the head and neck, increased thoracic kyphosis, shortening of the hip and knee flexors are responsible for the characteristic posture of AS patients. Furthermore, spinal and peripheral joint involvement may result in physical limitations and disability, ${ }^{[4]}$ and the propensity for falling could increase because of the poor posture and impaired mobility. Therefore, understanding the impact of AS on fall risk may elucidate the possible mechanism that causes disability in this patient population and permit more effective management of this disease. A few studies ${ }^{[5-9]}$ exist that have focused on postural balance in patients with AS, but these produced conflicting results. Furthermore, there is no quantitative data on fall risk related to AS. The Tetrax Interactive Balance System is reliable for evaluating postural balance and has been used to evaluate fall risk in some clinical studies in recent years. ${ }^{[10-12]}$

The aim of this study was to investigate whether patients with AS have a higher fall risk than healthy subjects and to determine if there was any association between this risk and the clinical features of AS.

\section{PATIENTS AND METHODS}

\section{Participants}

Forty AS patients (28 males, 12 females; mean $37.20 \pm 9.92$ years; range 20 to 60 years) who fulfilled the modified New York criteria ${ }^{[13]}$ and forty age- and gender-matched healthy controls were enrolled in this study. All individuals provided their written informed consent to participate, and the study was approved by the university research ethics committee. Patients who had been diagnosed with AS for at least one year were included. Those with vestibular disorders, concomitant neurological or psychiatric disease, severe visual or auditory impairments, and orthopedic problems in the lower extremities due to other issues were excluded from the study. After a detailed physical examination that included anthropometric measurements to determine body mass index (BMI), the participants' demographic information was obtained. In addition, the patient's history of falls for the previous 12 months was ascertained via interview. A fall was defined as an unintentional coming to the ground or other lower level without sustaining a violent blow, loss of consciousness, or sudden onset of paralysis, as occurs with a stroke or epileptic seizure. ${ }^{[14]}$ Retrospective falls were also assessed during the interview.

\section{Assessment of fall risk}

All subjects in the study were tested using the Tetrax Interactive Balance System (Sunlight Medical Ltd., Tel Aviv, Israel), which uses posturography, a method based on the assessment of vertical pressure fluctuations on four independent force plates, each placed beneath the two heels and toes of the subject while standing in an upright position. The standard examination consists of eight positions that are held for 32 seconds. Two of the positions occur with the head straight and eyes open while standing on a solid surface and elastic pads, respectively. Two more are in the same position but with the eyes closed. Two additional positions are with the head turned to the left and right while standing on a solid service, and the remaining two positions are the same but with the head tilted down. The software of the Tetrax system elaborates stability, weight distribution, synchronizations, and sway intensity. A fall index derived from the balance parameters established by this device has been developed to produce a score that expresses this risk based on the patient's specific balance factors that affect falling. This score rates the risk on a scale from 0-100 in which 0 indicates no risk of falling and 100 represents the extreme likelihood of falling. ${ }^{[10]}$ All of our participants were tested in the afternoon to avoid morning stiffness.

\section{Assessment of patients with AS}

The Bath Ankylosing Spondylitis Disease Activity Index (BASDAI) is a patient- reported measure of AS disease activity. This index uses a $10 \mathrm{~cm}$ visual analog scale (VAS) to measure the severity of fatigue, spinal and peripheral joint pain, localized tenderness, 
and morning stiffness in patients with AS. The final BASDAI score ranges from $0-10$, with lower numbers representing less severe disease activity. ${ }^{[15]}$

The Bath Ankylosing Spondylitis Functional Index (BASFI) consists of 10 questions designed to determine the degree of functional limitation in patients with AS. Each question is answered using a $10 \mathrm{~cm}$ VAS with a recall period of the previous week. The mean of the ten scales gives the BASFI score a value between 0 and 10 , with lower scores indicating less functional limitation. ${ }^{[16]}$ It has been proven that the Turkish versions of the BASDAI and BASFI are reliable and valid. ${ }^{[17,18]}$

The Bath Ankylosing Spondylitis Metrology Index (BASMI) is a validated composite index of four spinal measures (cervical rotation, tragus-to-wall distance, the modified Schober's test, and lateral lumbar flexion) and one hip mobility measure (intermalleolar distance). Each measure is assigned a score from 0-2, with higher scores signifying greater impairment in mobility. ${ }^{[19]}$

The Ankylosing Spondylitis Quality of Life (ASQoL) scale is a disease-specific instrument designed to measure health-related quality of life in patients with AS and contains 18 yes or no questions with a total score ranging from 0-18. Lower scores represent better QoL. ${ }^{[20]}$

\section{Statistical analysis}

All statistical analyses were performed using the SPSS version 15.0 for Windows software program (SPSS Inc., Chicago, IL, USA). Descriptive statistics were used for the demographic characteristics. For continuous variables, the significance of the differences was analyzed using Student's t-test while categorical variables were analyzed with a chi-square test. The median value for the fall risk index was calculated for both the patients with AS and the healthy controls. In order to determine whether there was a difference in the ratio of fallers between the individuals who had a fall risk index either below the median value or above the median value, a chi-square test was utilized. An analysis was performed for both study groups, and Spearman's correlation coefficient was calculated to determine the relationship between the clinical features and the risk of falling within the AS group since some of these variables were on an

Table 1. Demographic characteristics and fall risk in the patients with ankylosing spondylitis and the controls

\begin{tabular}{|c|c|c|c|c|c|c|c|}
\hline & \multicolumn{3}{|c|}{ AS patients $(n=40)$} & \multicolumn{3}{|c|}{ Controls $(\mathrm{n}=40)$} & \multirow[b]{2}{*}{$p$} \\
\hline & $\mathrm{n}$ & $\%$ & Mean \pm SD & $\mathrm{n}$ & $\%$ & Mean \pm SD & \\
\hline \multicolumn{8}{|l|}{ Gender } \\
\hline Male & 28 & 70 & & 28 & 70 & & \\
\hline Female & 12 & 30 & & 12 & 30 & & \\
\hline Age (years) & & & $37.20 \pm 9.92$ & & & $37.50 \pm 9.63$ & 0.891 \\
\hline Body mass index $\left(\mathrm{kg} / \mathrm{m}^{2}\right)$ & & & $24.30 \pm 3.55$ & & & $23.52 \pm 3.88$ & 0.349 \\
\hline Fall risk index & & & $40.22 \pm 26.72$ & & & $24.32 \pm 12.27$ & 0.001 \\
\hline \multicolumn{8}{|l|}{ History of falls } \\
\hline No & 32 & 80 & & 38 & 95 & & \multirow{2}{*}{0.043} \\
\hline Yes & 8 & 20 & & 2 & 5 & & \\
\hline Fall risk index for non-fallers & & & $30.34 \pm 16.88$ & & & $22.82 \pm 10.58$ & 0.033 \\
\hline \multicolumn{8}{|l|}{ Marital status } \\
\hline Single & 9 & 22.5 & & 9 & 22.5 & & \multirow{3}{*}{0.897} \\
\hline Married & 29 & 72.5 & & 28 & 70 & & \\
\hline Widow(er) & 2 & 5 & & 3 & 7.5 & & \\
\hline \multicolumn{8}{|l|}{ Education } \\
\hline Primary school & 19 & 47.5 & & 17 & 42.5 & & \multirow{3}{*}{0.761} \\
\hline High school & 8 & 20 & & 12 & 30 & & \\
\hline University & 13 & 32.5 & & 11 & 27.5 & & \\
\hline \multicolumn{8}{|l|}{ Vocation } \\
\hline Unemployed & 7 & 17.5 & & 6 & 15 & & \multirow{6}{*}{0.959} \\
\hline Housewife & 10 & 25 & & 7 & 17.5 & & \\
\hline Government official & 11 & 27.5 & & 12 & 30 & & \\
\hline Employee & 7 & 17.5 & & 9 & 12.5 & & \\
\hline Self-employed & 2 & 5 & & 2 & 5 & & \\
\hline Retired & 3 & 7.5 & & 4 & 10 & & \\
\hline
\end{tabular}


ordinal scale. In all analyses, $p$ values of $<0.05$ were considered to be statistically significant.

\section{RESULTS}

There were no differences between the AS patients and the controls regarding the sociodemographic characteristics $(p>0.05)$. The mean fall risk index of the AS patients was significantly higher than for the control group $(40.22 \pm 26.72$ and $24.32 \pm 12.27$, respectively) $(\mathrm{p}<0.05)$ (Table 1$)$. Also, when we analyzed the difference in the fall risk index between the two groups by excluding those who had a fall history, the mean fall risk indices were reduced to $30.34 \pm 16.88$ and $22.82 \pm 10.58$ for the non-falling AS patients and healthy controls, respectively. However, there was still a statistically significant difference in the fall risk index between the two groups of participants with no history of falling $(p=0.033)$ (Table 1). Furthermore, the distribution of the fall risk index scores in the patients with AS differed significantly from the controls (Figure 1). The ratio of fallers was also higher among the AS patients $(\mathrm{p}<0.05)$. In addition, the AS patients with a Tetrax fall risk index of lower than 36 , the median value, had no history of falling within the previous year, whereas those with a score of 36 or higher had a $40 \%$ positive history of falling. $(\mathrm{p}<0.05)$ (Table 2$)$.

The disease duration of the AS patients was between one and 29 years (median 7 years). Thirty percent of these patients had peripheral articular involvement, and $15 \%$ had extraarticular findings. On the other hand the median values of AS diseasespecific instrument scores were BASDAI 3.5, BASFI 2.4, BASMI 1.5, ASQoL 9.5 respectively (Table 3).

Fall risk and BASDAI $(\mathrm{r}=0.713, \mathrm{p}<0.001)$, BASFI $(\mathrm{r}=0.751, \mathrm{p}<0.001)$, BASMI $(\mathrm{r}=0.527, \mathrm{p}<0.001)$, ASQoL $(\mathrm{r}=0.627, \mathrm{p}<0.001)$ were positively and significantly associated. Whereas age, gender, body mass index and disease duration were not found to be related with fall risk ( $>>0.05)$ (Table 4).

\section{DISCUSSION}

In this cross-sectional study, we investigated whether patients with AS have a higher fall risk than healthy controls and tried to determine which clinical and demographical factors are associated with this phenomenon. Our results demonstrated significant differences between the AS and control subjects according to fall risk and history of falling. The BASDAI, BASFI, BASMI, and ASQoL were also found to be positively associated with fall risk in the patients with AS. However, we could not establish a correlation between fall risk and age, gender, BMI, or disease duration.

Since AS leads to permanent posture and mobility problems, the number of studies investigating the postural stability of these patients has increased in

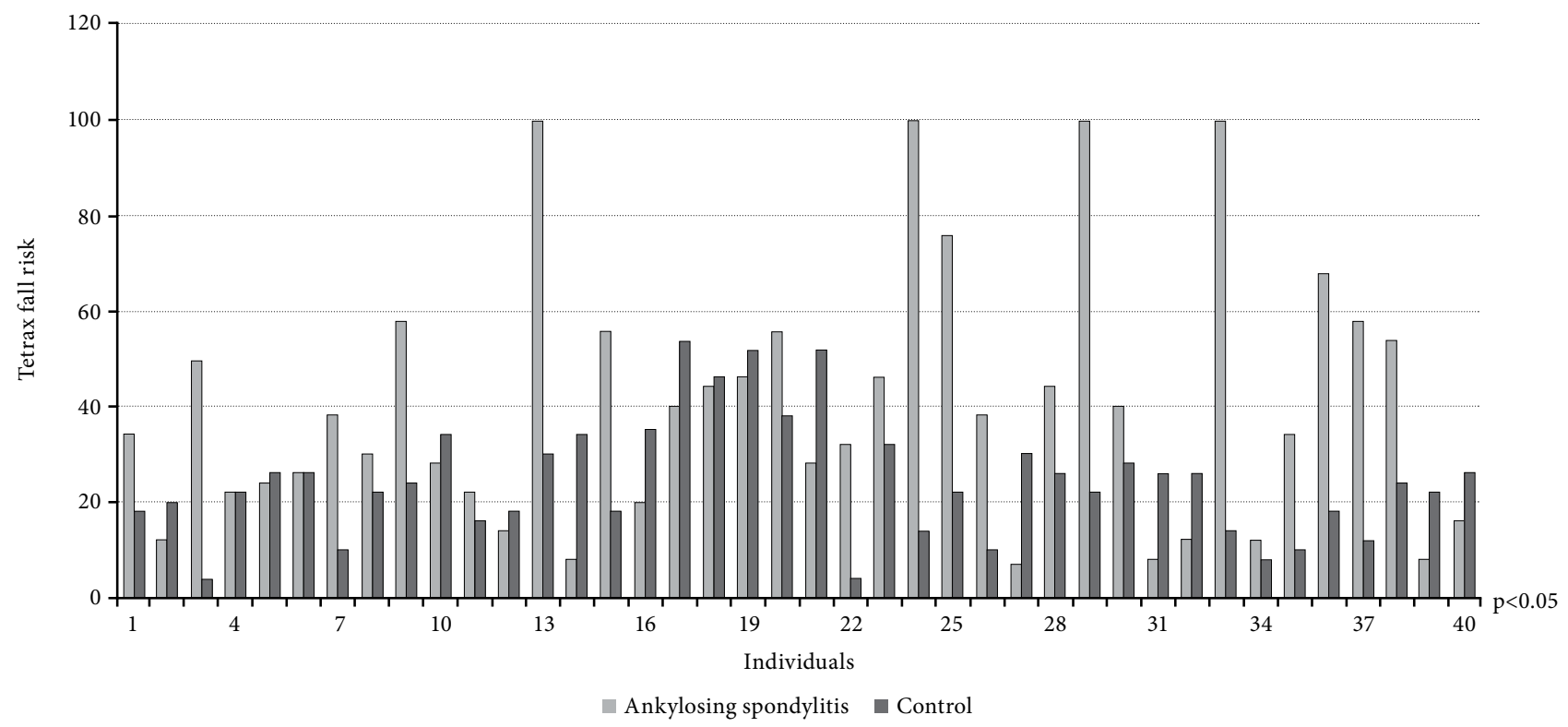

Figure 1. The distribution of fall risk index scores in patients with ankylosing spondylitis and controls. 


\begin{tabular}{|c|c|c|c|c|c|}
\hline & \multicolumn{4}{|c|}{ Fall history } & \multirow[b]{3}{*}{$p$} \\
\hline & \multicolumn{2}{|c|}{ Negative } & \multicolumn{2}{|c|}{ Positive } & \\
\hline & $\mathrm{n}$ & $\%$ & $\mathrm{n}$ & $\%$ & \\
\hline \multicolumn{6}{|l|}{ Fall risk index for AS patients } \\
\hline Above the median fall risk $(\geq 36)$ & 12 & 60 & 8 & 40 & \multirow{2}{*}{0.002} \\
\hline Below the median fall risk $(<36)$ & 20 & 100 & 0 & 0 & \\
\hline \multicolumn{6}{|l|}{ Fall risk index for controls } \\
\hline Above the median fall risk $(\geq 23)$ & 18 & 90 & 2 & 10 & \multirow{2}{*}{0.244} \\
\hline Below the median fall risk $(<23)$ & 20 & 100 & 0 & 0 & \\
\hline AS: Ankylosing spondylitis & & & & & \\
\hline
\end{tabular}

recent years, ${ }^{[5-9]}$ but there have been conflicting results. Some studies ${ }^{[5,8,9]}$ reported that AS patients had poor postural balance, but others ${ }^{[6,7]}$ noted good postural balance in those with this disease. Murray et al. ${ }^{[5]}$ were the first to show by quantitative measurement that a significant proportion of AS patients have poorer balance than normal subjects. They used sway magnetometry to evaluate balance and suggested that poor balance was not a problem for all AS patients and that the majority were actually within normal limits. In another study, it was shown that postural stability, as evaluated by the Biodex System SD (Biodex Medical Systems, Inc. Shirley, NY, USA) decreased in patients with AS, especially in advanced cases. ${ }^{[8]}$ Furthermore, in a recent study by Vergara et al., ${ }^{[9]}$ they concluded that standing postural control, which was evaluated by static force platforms, was altered in patients with AS. In accordance with these studies, we determined that the fall risk index derived from balance factors was higher in patients with AS and that significantly more AS patients than healthy controls had a positive history of falls. Diseasespecific instruments of AS that reflect the progression of disease have also been correlated with the fall risk index. In contrast to these studies, Aydog et al. ${ }^{[6]}$ evaluated 70 AS and 35 healthy controls using the Biodex System SD to determine the dynamic postural balance and suggested that AS had no negative effect on postural stability. In another study, Adam et al. ${ }^{[7]}$ utilized the same Tetrax Interactive Balance System that we used to evaluate stability, sway intensity, and weight distribution and to investigate whether AS patients had poorer balance than healthy subjects due to postural changes. They found no statistically significant differences in the balance parameters between the two groups. However, Adam et al. ${ }^{[7]}$

Table 3. Clinical variables in the patients with ankylosing spondylitis $(n=40)$

\begin{tabular}{|c|c|c|c|c|}
\hline & $\mathrm{n}$ & $\%$ & Median & Min.-max. \\
\hline Disease duration (years) & & & 7 & $1-29$ \\
\hline Bath Ankylosing Spondylitis Disease Activity Index & & & 3.5 & $0-8.8$ \\
\hline Bath Ankylosing Spondylitis Functional Index & & & 2.4 & $0-9.2$ \\
\hline Bath Ankylosing Spondylitis Metrology Index & & & 1.5 & $0-10$ \\
\hline Ankylosing Spondylitis Quality of Life & & & 9.5 & $0-18$ \\
\hline \multicolumn{5}{|l|}{ Peripheral arthritis } \\
\hline Absent & 28 & 70 & & \\
\hline Present & 12 & 30 & & \\
\hline \multicolumn{5}{|l|}{ Extraarticular findings } \\
\hline No & 34 & 85 & & \\
\hline Yes & 6 & 15 & & \\
\hline \multicolumn{5}{|l|}{ Medicine } \\
\hline Only non-steroidal anti-inflammatory drug & 3 & 7.5 & & \\
\hline Non-steroidal anti-inflammatory drug + DMARD & 22 & 55 & & \\
\hline Biological agents & 12 & 30 & & \\
\hline Non-steroidal anti-inflammatory drug + biological agents & 3 & 7.5 & & \\
\hline
\end{tabular}




\begin{tabular}{|c|c|c|}
\hline & $\begin{array}{c}\text { Fall risk index } \\
\text { Spearman's correlation coefficient } \\
\text { (Spearman's rho) }\end{array}$ & \multirow[b]{2}{*}{$p$} \\
\hline & $\mathrm{r}$ & \\
\hline Gender & -0.062 & 0.706 \\
\hline Age & -0.021 & 0.898 \\
\hline Body mass index & 0.055 & 0.736 \\
\hline Duration of disease & 0.276 & 0.085 \\
\hline Bath Ankylosing Spondylitis Disease Activity Index & 0.713 & $<0.001$ \\
\hline Bath Ankylosing Spondylitis Functional Index & 0.751 & $<0.001$ \\
\hline Bath Ankylosing Spondylitis Metrology Index & 0.527 & $<0.001$ \\
\hline Ankylosing Spondylitis Quality of Life & 0.627 & $<0.001$ \\
\hline
\end{tabular}

reported that the reason why they found no balance problems was possibly due to the small numbers of patients with severe disease, such as dorsal kyphosis, a source of postural impairment, in their studies. The same authors also concluded that postural balance might have been compensated for by other unaffected joints in the lower extremities. Unlike those studies, almost one-third of our patients had severe disease with notable postural impairment.

Poor postural balance is one of the major risk factors for falling, ${ }^{[21]}$ and deterioration in postural stability in patients with AS may contribute to the number of falls. Currently, no instruments exist that can determine the fall risk in patients with AS, and to our knowledge, this is the first study involving AS patients that has attempted to compare fall risk with healthy controls. In order to examine balance in the AS patients, we assessed the fall risk using a static posturographic device. Retrospective falls were also assessed during the patient interviews. We found significant differences in the fall risk and history of falls between the patients with AS and healthy controls. In addition, we demonstrated that AS patients who had a positive history of falls have a higher fall risk index than non-falling AS patients. This result may be explained by the impaired balance in AS due to postural and biomechnical changes.

Fall index assessment with the Tetrax Interactive Balance System is designed to assess the individual's risk of falling, and this index reflects balance factors that influence this risk, including contrast sensitivity, proprioception, and sway. ${ }^{[22]}$ Recent studies ${ }^{[10,23]}$ have reported that in a sample of non-institutionalized elderly people over the age of 65 , a posturographic evaluation appears to be a more sensitive tool than clinical tests for identifying patients who are at high risk for recurrent falls.

There is data suggesting that patients with AS have an increased rate of spinal cord injuries (SCIs), ${ }^{[2-26]}$ which is directly correlated with the increased incidence of vertebral fractures and fracture risk that is associated with the risk of falling and osteoporosis in AS patients. ${ }^{[24]}$ Hence, understanding the impact of AS on fall risk and determining which clinical features are associated with this risk should be an important goal for healthcare professionals involved in the treatment of AS patients. Moreover, having the ability to identify the risks related to future falls is necessary in order to target high risk patients for preventive intervention.

Since disease-specific instruments of AS reflect the progression of disease, the correlation between these tools and fall risk is expected. Potential contributors to altered postural control may include pain, inflammation, axial stiffness, and increased mechanical stiffness of the affected joints, all of which determine disease activity, spinal mobility, functional impairment, and QoL. ${ }^{[9]}$ Thus, changes in disease-specific instruments of AS may lead to impaired postural control and the association of altered postural control with increased fall risk. Previous data related to the association between balance and the clinical features of AS are contradictory. ${ }^{[5-9]}$ Durmuş et al. ${ }^{[8]}$ concluded that the decreased postural stability in patients with AS was associated with increased kyphosis seen during the course of the disease. However, another study showed 
that postural control was related to measurements of functional impairment and disease activity as determined by clinical indices. ${ }^{[9]}$ In addition, Aydog et al. ${ }^{[6]}$ observed a positive correlation only between tragus-to-wall distance and postural balance. No other correlation was detected between stability indices and the BASMI or disease duration of their patients. In yet another study, Murray et al. ${ }^{[5]}$ showed no significant relationships between balance and any of the quantitative descriptions of posture. Finally, Adam et al. ${ }^{[7]}$ also found no correlations between balance parameters and the quantitative measurements of posture and disease duration. In this study, we demonstrated that increased fall risk was associated with poorer spinal mobility, functional status, QoL, and higher disease activity in patients with AS.

Our study had a few potential limitations, including its cross-sectional design and the relatively small sample size. Moreover, the indirect assessment of fall risk and unavailability of data related to the prospective frequency of falls precluded us from making clear assertions.

In conclusion, the risk of falling in AS patients was higher than for healthy controls in this study. In addition, poorer spinal mobility, functional status, QoL, and higher disease activity for AS were found to be related to an increased fall risk. Further longitudinal studies with larger AS patient groups are required to more accurately identify the risk of falling in these patients and to clearly define the relationship between fall risk and clinical features.

\section{Declaration of conflicting interests}

The authors declared no conflicts of interest with respect to the authorship and/or publication of this article.

\section{Funding}

The authors received no financial support for the research and/or authorship of this article.

\section{REFERENCES}

1. Gran JT, Husby G. The epidemiology of ankylosing spondylitis. Semin Arthritis Rheum 1993;22:319-34.

2. Sieper J, Braun J, Rudwaleit M, Boonen A, Zink A. Ankylosing spondylitis: an overview. Ann Rheum Dis 2002;61 Suppl 3:iii8-18.

3. McLeod C, Bagust A, Boland A, Dagenais P, Dickson R, Dundar Y, et al. Adalimumab, etanercept and infliximab for the treatment of ankylosing spondylitis: a systematic review and economic evaluation. Health Technol Assess 2007;11:1-158, iii-iv.
4. Khan MA. Ankylosing spondylitis--the history of medical therapies. Clin Exp Rheumatol 2002;20:S3-5.

5. Murray HC, Elliott C, Barton SE, Murray A. Do patients with ankylosing spondylitis have poorer balance than normal subjects? Rheumatology (Oxford) 2000;39:497-500.

6. Aydog E, Depedibi R, Bal A, Eksioglu E, Unlü E, Cakci A. Dynamic postural balance in ankylosing spondylitis patients. Rheumatology (Oxford) 2006;45:445-8.

7. Adam M, Leblebici B, Erkan AN, Bagis S, Akman MN. Ankylosing spondylitis and postural balance. Rheumatism 2008;23:87-90.

8. Durmus B, Altay Z, Ersoy Y, Baysal O, Dogan E. Postural stability in patients with ankylosing spondylitis. Disabil Rehabil 2010;32:1156-62. doi: 10.3109/09638280903428310.

9. Vergara ME, O'Shea FD, Inman RD, Gage WH. Postural control is altered in patients with ankylosing spondylitis. Clin Biomech (Bristol, Avon) 2012;27:334-40. doi: 10.1016/j.clinbiomech.2011.10.016.

10. Ozdemir O, Gökce Kutsal Y. Fall risk assessment of elderly by using posturography. Turkish Journal of Geriatrics 2009;12:177-80.

11. Diracoglu D, Cihan C, Issever H, Aydin R. Postural performance in patients with cervical radiculopaty. Turk J Phys Med Rehab 2009;55:153-7.

12. Alkan H, Topuz O, Yıldız N, Alkan S, Sarsan A, Ardıç F. Efficacy of home-based exercise program and postural biofeedback therapy in reducing risk of falling among osteoporotic women over 65 years of age. Turkish Journal of Geriatrics 2011;14:26-34.

13. van der Linden S, Valkenburg HA, Cats A. Evaluation of diagnostic criteria for ankylosing spondylitis. A proposal for modification of the New York criteria. Arthritis Rheum 1984;27:361-8.

14. Gibson MJ, Andres RO, Isaacs B, Radebaugh T, WormPetersen J. The prevention of falls in later life. A report of the Kellogg International Work Group on the prevention of falls by the elderly. Dan Med Bull 1987;34(Suppl 4):1-24.

15. Garrett S, Jenkinson T, Kennedy LG, Whitelock H, Gaisford P, Calin A. A new approach to defining disease status in ankylosing spondylitis: the Bath Ankylosing Spondylitis Disease Activity Index. J Rheumatol 1994;21:2286-91.

16. Calin A, Garrett S, Whitelock H, Kennedy LG, O'Hea J, Mallorie P, et al. A new approach to defining functional ability in ankylosing spondylitis: the development of the Bath Ankylosing Spondylitis Functional Index. J Rheumatol 1994;21:2281-5.

17. Akkoc Y, Karatepe AG, Akar S, Kirazli Y, Akkoc N. A Turkish version of the Bath Ankylosing Spondylitis Disease Activity Index: reliability and validity. Rheumatol Int 2005;25:280-4.

18. Yanik B, Gürsel YK, Kutlay S, Ay S, Elhan AH. Adaptation of the Bath Ankylosing Spondylitis Functional Index to the Turkish population, its reliability and validity: functional assessment in AS. Clin Rheumatol 2005;24:41-7. 
19. Jenkinson TR, Mallorie PA, Whitelock HC, Kennedy LG, Garrett SL, Calin A. Defining spinal mobility in ankylosing spondylitis (AS). The Bath AS Metrology Index. J Rheumatol 1994;21:1694-8.

20. Doward LC, Spoorenberg A, Cook SA, Whalley D, Helliwell PS, Kay LJ, et al. Development of the ASQoL: a quality of life instrument specific to ankylosing spondylitis. Ann Rheum Dis 2003;62:20-6.

21. Alpini D, Kohen-Ratz R, Braun R, Burstin A, Tesio L, Pugnetti L, et al. Falls in the elderly: the development of a risk questionnaire and posturographic findings. Int Tinnitus J 2001;7:105-8.

22. Lord SR, Clark RD, Webster IW. Physiological factors associated with falls in an elderly population. J Am Geriatr Soc 1991;39:1194-200.
23. Buatois S, Gueguen R, Gauchard GC, Benetos A, Perrin PP. Posturography and risk of recurrent falls in healthy non-institutionalized persons aged over 65. Gerontology 2006;52:345-52.

24. Alaranta H, Luoto S, Konttinen YT. Traumatic spinal cord injury as a complication to ankylosing spondylitis. An extended report. Clin Exp Rheumatol 2002;20:66-8.

25. Jacobs WB, Fehlings MG. Ankylosing spondylitis and spinal cord injury: origin, incidence, management, and avoidance. Neurosurg Focus 2008;24:E12. doi: 10.3171/ FOC/2008/24/1/E12.

26. Cooper C, Carbone L, Michet CJ, Atkinson EJ, O'Fallon WM, Melton LJ 3rd. Fracture risk in patients with ankylosing spondylitis: a population based study. J Rheumatol 1994;21:1877-82. 